$10-1-1978$

\title{
Serologic and Hematologic Values of Bison in Colorado
}

Edward O. Keith

Colorado State University - Fort Collins

James Ellis

Colorado State University - Fort Collins

Robert W. Phillips

Colorado State University - Fort Collins

Maxine M. Benjamin

Colorado State University - Fort Collins

Find out more information about Nova Southeastern University and the Halmos College of Natural Sciences and Oceanography.

Follow this and additional works at: https://nsuworks.nova.edu/occ_facarticles

Part of the Marine Biology Commons, and the Oceanography and Atmospheric Sciences and Meteorology Commons

\section{NSUWorks Citation}

Edward O. Keith, James Ellis, Robert W. Phillips, and Maxine M. Benjamin. 1978. Serologic and Hematologic Values of Bison in Colorado .Journal of Wildlife Diseases , (4) : 493 -500. https://nsuworks.nova.edu/occ_facarticles/680.

This Article is brought to you for free and open access by the Department of Marine and Environmental Sciences at NSUWorks. It has been accepted for inclusion in Marine \& Environmental Sciences Faculty Articles by an authorized administrator of NSUWorks. For more information, please contact nsuworks@nova.edu. 


\section{SEROLOGIC AND HEMATOLOGIC VALUES OF BISON IN COLORADO"}

EDWARD O. KEITH and JAMES E. ELLIS, Natural Resource Ecology Laboratory, Colorado State Univeraity, Fort Collins, Colorado 80523, USA

ROBERT W. PHILJIPS, Department of Physiology and Biophysics, Colorado State University, Fort Collins. MAXINE M. BENJAMIN, Department of Pathology, Colorado State University, Fort Collins.

Abstract: Recent economic and aesthetic interest in North American bison (Bison bison) has lead to increased interstate transport of these animals. Serologic and hematologic standards for bison are needed to detect disease in transported animals as well as within herds. This paper describes variation in blood physiological parameters in bison caused by variations in diet and season. Blood was taken from six bison and analyzed for serologic and hematologic parameters. Significant variation was found in blood urea nitrogen, chloride, cholesterol, creatinine, eosinophil, glucose, hemoglobin, lactic dehydrogenase, leukocyte, packed cell volume, potassium, serum globulin, serum glutamic oxalacetic transaminase, SGPT, and sodium levels between animals receiving a high energy-high nitrogen diet and animals receiving a low energy-low nitrogen diet.

\section{INTRODUCTION}

Bison are becoming increasingly popular for aesthetic and economic reasons creating a need for baseline information. Transport of bison also has become more frequent. Therefore, the need for standards to evaluate hematologic and serologic samples from these animals has arisen. Data presented here contribute to determining the range of normal variation in bison blood values.

\section{MATERIALS AND METHODS}

Values presented were taken from six bison maintained at the Pawnee Site, field research facility of the Natural Resource Ecology Laboratory, Colorado State University, located on the United States Department of Agriculture, Science and Education Administration Federal Research, Central Plains Experimental Range in northeastern Colorado. The location, vegetation, physiography, and climate have been de scribed by Jameson. ${ }^{7}$ The animals had been used for diet selection and digestibility studies from 1969 to $1972 .{ }^{12}$ During blood sampling, the animals were being used to investigate nitrogen metabolism, especially urea recycling. ${ }^{8}$

Samples were taken on 1 December 1975, 1 March 1976, 9 June 1976, and 21 October 1976. From 11 November 1975 to 1 May 1976, the animals were divided into two groups, one of which received a high energy-high nitrogen diet consisting of crested wheatgrass hay $(6 \%$ crude protein, $4030 \mathrm{cal} / \mathrm{g}$ gross energy) and a supplement (Pawnee mix: 15\% crude protein, $4160 \mathrm{cal} / \mathrm{g}$ gross energy). The other group received a low energylow nitrogen diet consisting solely of the crested wheatgrass hay. Both groups were fed ad libitum. After 1 May 1976 all animals received approximately $11 \mathrm{~kg}$ of supplement per day, and grazed freely on a 16.2-ha native pasture (11\% crude pro-

T. This paper reports on work supported in part by National Science Foundation Grants BMS73-02027 A02, DEB73-02027 A03, and DEB73-02027 A04 to the Grassland Biome, U.S. International Biological Program, for "Analysis of Structure, Function, and Utilization of Grassland Ecosystems." 
tein). On 1 October 1976 the bison began receiving a different crested wheatgrass hay in addition to the pasture forage and Pawnee mix which was probably similar to the hay fed previously.

At the start of feeding trials, six animals obtained from the Wichita Mountains Wildlife Refuge, Oklahoma were available for blood sampling. Four of these had rumen fistulas and two had esophageal fistulas (Table 1). However, in September, 1976 an animal (\#10) died of unknown causes. Samples were taken from the remaining five animals on 21 October. Necropsy of Animal 10 did not reveal any single major cause of death, although encapsulated kidneys were implicated.

Blood was taken from the left external jugular vein and placed in two Vacutainers, ${ }^{a}$ one containing a premeasured amount of EDTA anticoagulant. The blood was kept chilled during transport to the Clinical Pathology Laboratory, Veterinary Hospital, Colorado State University, for analysis. Time from collection of blood until delivery to the lab varied from 2 to $6 \mathrm{~h}$, depending on the order of animal sampled. A Hycel Mark $17^{\text {G }}$ was used to determine serological values, and a Coulter Counter Model FN $\square$ was used for total leukocyte and erythrocyte counts. Packed cell volume was determined by micro-hematocrit and differential counts were made from Wrightstained blood smears examined under oil immersion using standard counting techniques. Student's-T tests ${ }^{4}$ were used to detect significant differences between the groups for selected parameters. Significant differences are discernible in Table 2. Values followed by the same letter indicate significant differences in the same row, or between diet groups for the first two sample dates.

\section{RESULTS}

Results of analyses are presented in Table 2. Because the two groups of bison were receiving different diets during the first two sampling dates, averages $( \pm 1$ SD) for each diet group (3 animals per group) are presented for the 1 December and 1 March sample dates. Data collected after completion of the diet trials, when all animals were receiving the same ration, are presented as mean values for all animals for the 9 June ( 6

TABLE 1. Diet groups of bison.

\begin{tabular}{llll}
\hline Group & Sex & Fistula Type† & Fistula Date \\
\hline Group A - High Diet & & & \\
Bison 15 & F & E & 1971 \\
Bison 10 & M & R & 16 Sept. 1975 \\
Bison 12 & F & R & 12 Dec. 1975 \\
Group B - Low Diet & & & \\
Bison 1 & M & E & 1971 \\
Bison 8 & F & R & 1971 \\
Bison 13 & F & R & 12 Dec. 1975 \\
\hline
\end{tabular}

${ }^{*} \mathrm{~F}=$ female; $\mathrm{M}=$ male.

$+E=$ esophageal; $R=$ ruminal.

[2] Becton, Dickinson and Company, Rutherford, New Jersey.

3 Hycel, Incorporated, Houston, Texas.

Coulter Diagnostics, 740 W. 83rd Ave., Hialeah, Florida 33014, USA. 


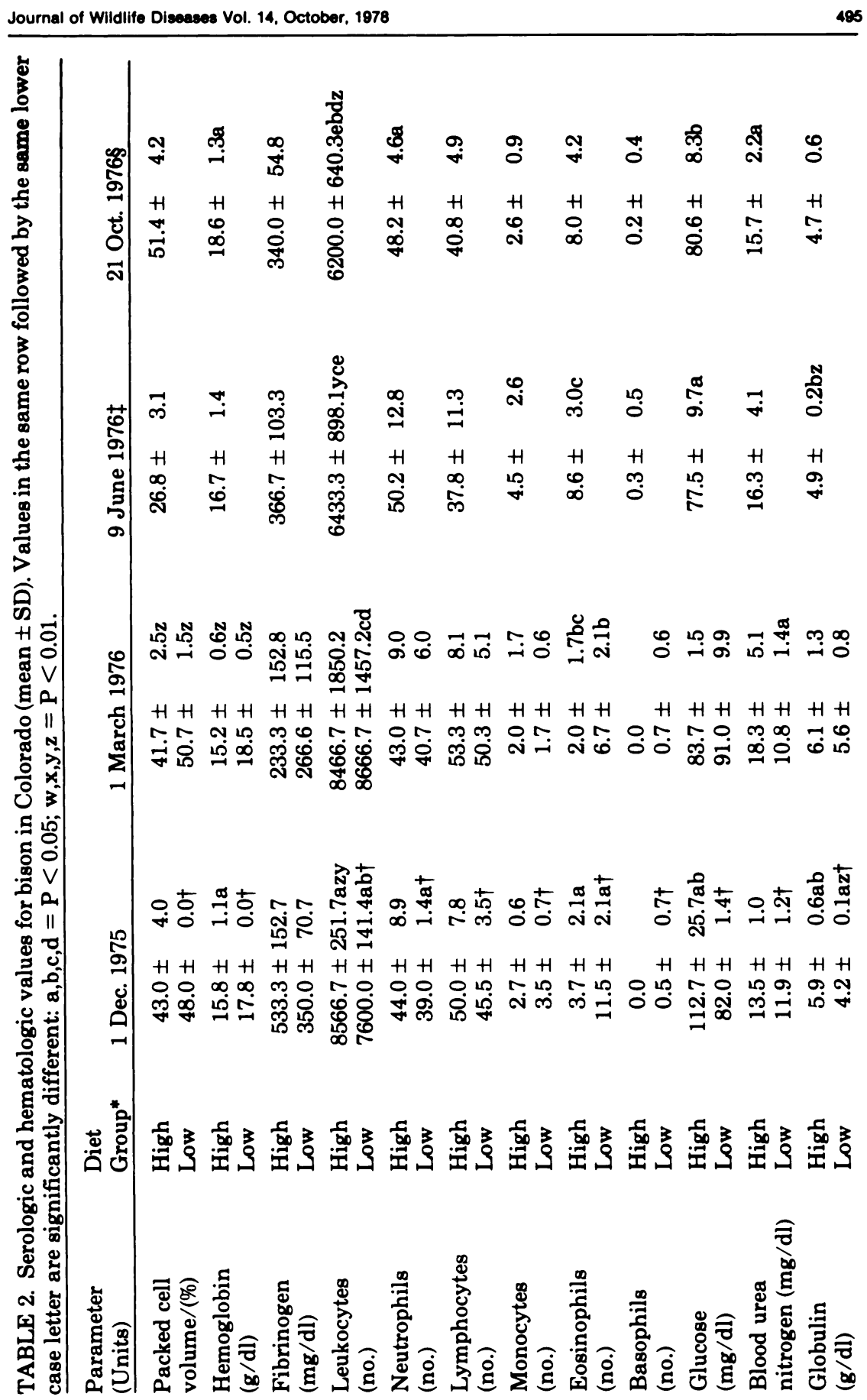




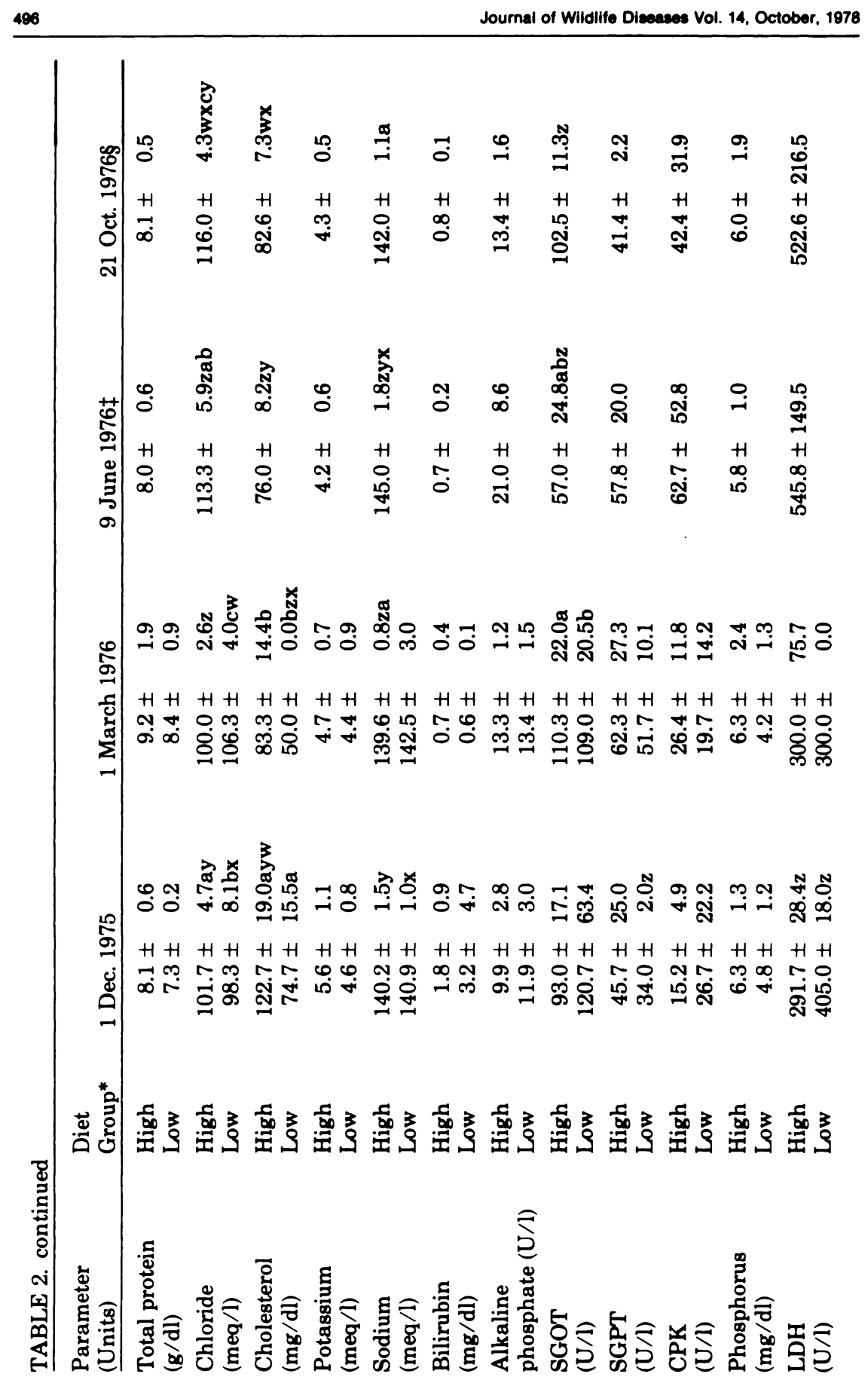


bison) and 21 October (5 bison) sample dates.

If the December and March data are pooled to give a total of six samples per group for an assessment of "winter" condition, the high diet group had significantly higher average BUN levels $(P<0.05)$ and average cholesterol levels $(\mathrm{P}<0.01)$ but had significantly lower packed cell volumes (hematocrit) $(\mathrm{P}<$ 0.01 ) than the low diet group.

In Table 3 the data for the 9 June and 21 October samples are compared to data presented by Mehrer, ${ }^{10}$ who examined 163 bison from five wildlife refuges across the United States, and to those of Marler, ${ }^{9}$ who examined 47 adult bison for hematological values and 25 for blood chemistry values, all in Kansas.

\section{DISCUSSION}

Payne et al. ${ }^{11}$ suggest three major sources of variation in blood physiolog. ical parameters. They are: 1) season, 2) genetics, and 3) production level for lactation. Other factors, he concedes, may have an effect; these include age, sex, and stage in lactation. However, Payne was dealing with uniformly fed, well-housed dairy cattle. Other authors ${ }^{2,6,13,14}$ have stressed that many environmental factors can cause variation in blood chemistry values. Drevemo et al. ${ }^{3}$ list other factors affecting blood physiological parameters. Among them are stress, disease, excitement, and circadian and diurnal rhythms. Using data from a variety of sources, Bailey ${ }^{1}$ compared various blood chemistry values for mule deer (Odocoileus hemionus) and whitetailed deer (O. virginianus) on varying planes of nutrition. Differences in blood chemistry values apparently caused by nutrition were evident. Torrel et al. ${ }^{16}$ dis cussed using blood urea nitrogen as an index to the nutritional status of sheep. BUN was correlated to nitrogen intake ( $r$ $=0.99)$ and weight gain $(\mathrm{r}=0.95)$.

Marler ${ }^{9}$ compared blood values for young (less than 2 years old) vs. old 


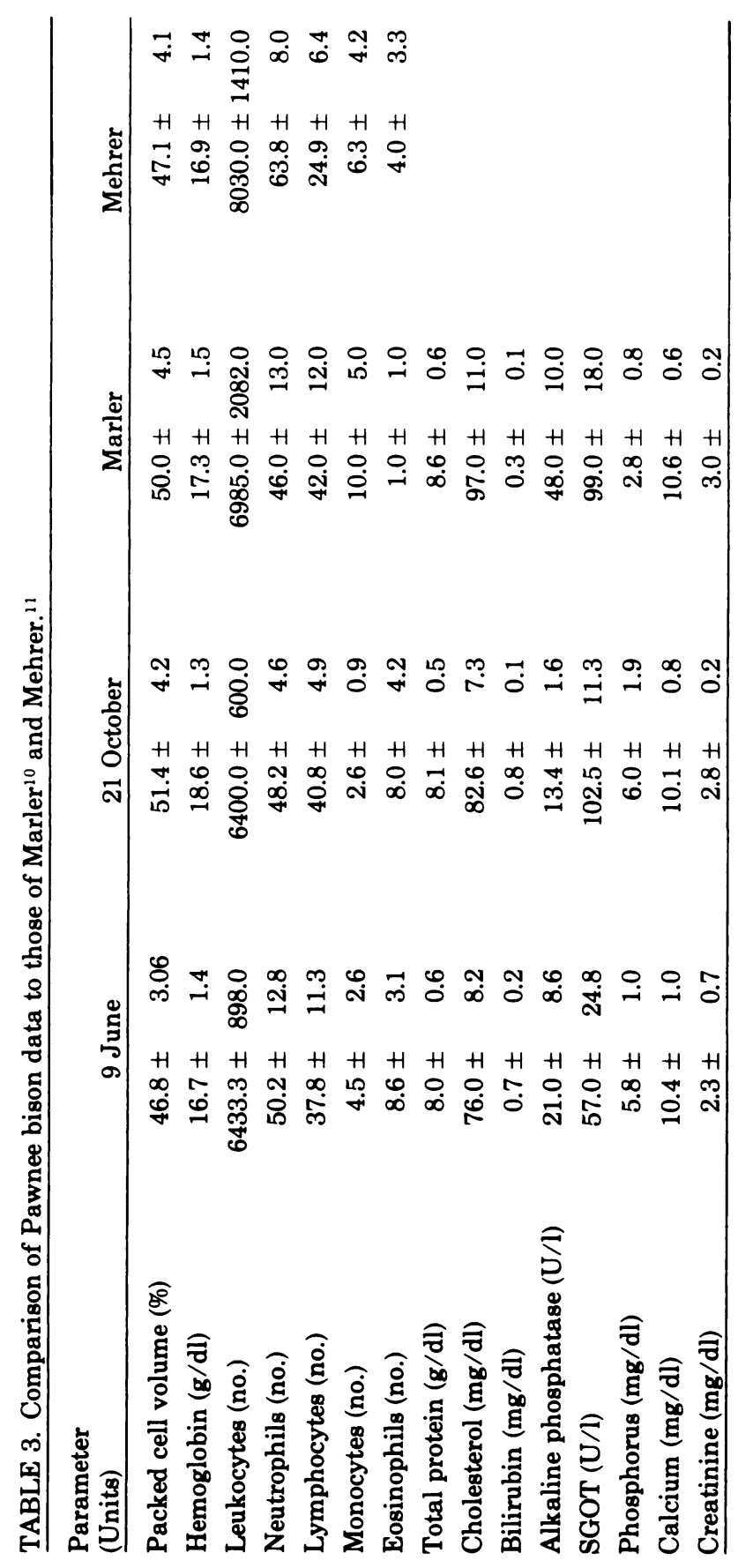


bison, and found significant differences in leukocyte numbers, neutrophil percentage, lymphocyte percentage, and cholesterol, alkaline phosphatase, and SGOT levels. Mehrer ${ }^{10}$ also found significant differences between age groups of male bison, but not of female bison. Because our animals were all about the same age, differences due to age were not distinguishable.

Our major interest was in variation of blood values caused by diet. Animals receiving a low protein diet in December had low serum globulin levels, while animals receiving an adequate diet had high globulin values. Animals receiving a high protein-high energy diet had high glucose, potassium, and cholesterol levels. BUN for both groups in December was slightly lower than later values, as were sodium, LDH, and SGPT. In March the groups were not as different as they were in December, the low diet group having more normal total protein and serum globulin levels, but lower cholesterol levels and the high diet group having a lower blood glucose average and a lower cholesterol level. The low BUN of the low diet group in winter may be caused by that group's low protein intake. $^{15}$
The low-diet group had significantly higher SGOT levels in March than in June, indicating that these animals were under some stress during this period. SGOT values for the high diet group in March, and for all animals in December and October were comparable to those obtained by Marler. ${ }^{9}$ Significantly high values could indicate cell necrosis and myopathy. ${ }^{5}$ Low LDH levels indicate that the animals were under little stress at the time of sampling, ${ }^{14}$ while higher levels have little meaning without isoenzyme determinations to identify the source.

A sidelight not evident from the data presented is that bison with esophageal fistulas had higher leukocytic counts than did other animals in the March samples. This perhaps is a reflection of stress caused by the fistula; however, counts were not different in any other sample period. SGOT levels in esophageally fistulated animals were not different in the March sample, indicating little cell necrosis in these animals. Except for this single aberration no significant differences were discernible between animals with different fistulas although we were unable to sample nonfistulated animals to examine the effects of fistulation itself.

\section{LITERATURE CITED}

1. BAILEY, J.A. 1969. Rumino-reticular contents and blood constituents as parameters of nutritional condition in North American deer. In: Recent Advances in Wildlife Nutrition: Papers from a Graduate Student Seminar in Wildlife Biology, J.A. Bailey and J.G. Nagy (Eds.) pp. 94-117. Colorado State Univ., Fort Collins, Colorado.

2. DIETERICH, R.A. and J.R. LUICK. 1971. Reindeer in biomedical research. Lab. Anim. Sci. 21: 817-824.

3. DREVEMO, S., J.G. GROOTENHUIS and L. KARSTAD. 1974. Blood parameters of wild ruminants in Kenya. J. Wildl. Dis. 10: 327-334.

4. EDWARDS, A.L. 1969. Statistical Analysis. Holt, Rinehart and Winston, Inc., New York. 244 pp.

5. FRANZMAN, A.W. 1971. Comparative physiologic values in captive and wild bighorn sheep. J. Wildl. Dis. 7: 105-108.

6. - 1972. Environmental sources of variation of bighorn sheep physiologic values. J. Wildl. Manage. 36: 924-932. 
7. JAMESON, D.A. 1969. General description of the Pawnee Site. US/IBP Grassland Biome Tech. Rep. No. 1. Colorado State Univ., Fort Collins, Colorado. 162 pp.

8. KEITH, E.O. and J.E. ELLIS. 1976. Urea recycling in bison. Paper presented at the 52nd annual meeting of the Southwestern and Rocky Mountain Division, AAAS, Tucson. Abs. publ. in J. Ariz. Acad. Sci. 11: 22.

9. MARLER, R.J. 1975. Some hematologic and blood chemistry values in two herds of American bison in Kansas. J. Wildl. Dis. 11: 97-100.

10. MEHRER, C.F. 1976. Some hematologic values in bison from five areas of the United States. J. Wildl. Dis. 12: 7-13.

11. PAYNE, J.M., G.J. ROWLANDS, R. MANSTON, S.M. DEW and W.H. PARKER. 1974. A statistical appraisal of the results of metabolic profile test on 191 herds in the BVA/ADAS joint exercise in animal health and productivity. Br. Vet. J. 130: 34-44.

12. PEDEN, D.G. 1972. The trophic relations of Bison bison to the shortgrass prairie. Ph.D. thesis. Colorado State University, Fort Collins, Colorado. 134 pp.

13. PEDERSEN, R.J. and A.A. PEDERSEN. 1975. Blood chemistry and hematology of elk. J. Wildl. Manage. 39: 617-620.

14. SEARCY, R.L. 1969. Diagnostic Biochemistry. McGraw-Hill Book Co., Inc., New York. 660 pp.

15. THORNE, T.P. 1970. Physiologic values in wild bighorn sheep/Ovis canadensis canadensis) at capture, after handling, and after captivity. J. Am. vet. med. Ass. 157: 647-650.

16. TORREL, D.T., I.D. HUME and W.C. WEIR. 1974. Factors affecting blood urea nitrogen and its use as an index to the nutritional status of sheep. J. Anim. Sci. 39: 435-440.

Received for publication 14 November 1977 